\title{
ANALISIS PENGARUH GAYA KEPEMIMPINAN TERHADAP KINERJA PEGAWAI PADA PT. KERETA API INDONESIA (PERSERO) TANJUNG KARANG
}

\author{
Icha Annissa Putri ${ }^{(1)}$, Andi Mulyadinata ${ }^{(2)}$, Khairul Saleh $^{(3)}$ \\ Fakultas Ekonomi Universitas Sang Bumi Ruwa Jurai \\ annisaputri_icha@gmail.com,andi.mulyadinata@fe.saburai.ac.id,khairul.saleh@fe.saburai.ac.id
}

\begin{abstract}
Abstrak. Gaya kepemimpinan merupakan norma perilaku yang dipergunakan oleh seseorang pada saat orang tersebut mencoba mempengaruhi perilaku orang lain. Masing-masing gaya tersebut memiliki keunggulan dan kelemahan. Seorang pemimpin akan menggunakan gaya kepemimpinan sesuai kemampuan dan kepribadiannya. Permasalahan dalam penelitian ini adalah apakah ada pengaruh gaya kepemimpinan terhadap kinerja pegawai pada PT Kereta Api Indonesia (Persero) Tanjung karang, sedangkan tujuan penelitian adalah untuk mengetahui pengaruh gaya kepemimpinan terhadap kinerja pegawai pada PT. Kereta Api Indonesia (Persero) Tanjung karang. Metode yang digunakan adalah metode analisis kualitatif dan analisis kuantitatif. Populasi dalam penelitian ini berjumlah 188 sedangkan sampel dalam penelitian ini berjumlah $19 \%$ jadi sampel dalam penelitian ini $188 \times 19 \%=36$ orang pegawai. Berdasarkan hasil hasil uji hipotesis analisis regresi linier sederhana diperoleh persamaan dimana $t_{\text {hitung }}$ untuk Gaya Kepemimpinan sebesar 4,629 sedangkan $t_{\text {tabel }}$ sebesar dengan $\mathrm{dk}\left(36-2\right.$ - 34) adalah 1.689 , jadi $t_{\text {hitung }} 4,629>t_{\text {tabel }} 0.05(36-2=$ $34)=1-689$, sehingga dapat diketahui bahwa gaya kepemimpinan berpengaruh positip signifikan terhadap Kinerja pegawai pada PT. Kereta Api Indonesia (Persero) Tanjung Karang, selain itu semakin baik gaya kepemimpinan yang dilakukan maka berdampak kepada kemajuan dan kualitas sumber daya manusia. Sedangkan dari hasil nilai Koefesien Determinasi ( $R$ Square) diperoleh nilai sebesar 0.334 atau secara statistik $33,4 \%$.
\end{abstract}

Kata kunci: Gaya, Kinerja, Pegawai, Pemimpin.

\section{PENDAHULUAN}

Sumber daya manusia merupakan faktor yang sangat penting dalam sebuah organisasi baik organisasi dalam skala besar maupun kecil. Pada organisasi berskala besar, sumber daya manusia dipandang sebagai unsur yang sangat menentukan dalam proses pengembangan usaha, peran sumber daya manusia menjadi semakin penting. Perkembangan dunia usaha akan terealisasi apabila ditunjang oleh sumber daya manusia yang berkualitas.

Dalam organisasi publik, bawahan bekerja selalu tergantung pada pimpinan. Bila pimpinan tidak memiliki kemampuan memimpin, maka tugas tugas yang sangat kompleks tidak dapat dikerjakan dengan baik. Apabila manajer mampu melaksanakan fungsi-fungsinya dengan baik, sangat mungkin organisasi tersebut dapat mencapai sasarannya. Suatu organisasi membutuhkan pemimpin yang efektif, yang mempunyai kemampuan mempengaruhi perilaku anggotanya atau anak buahnya.

Kepemimpinan merupakan salah satu isu dalam manajemen yang masih cukup menarik untuk diperbincangkan hingga dewasa ini. Media massa, baik elektronik maupun cetak, seringkali menampilkan opini dan pembicaraan yang membahas seputar kepemimpinan. Peran kepemimpinan yang sangat strategis dan penting bagi pencapaian misi, visi dan tujuan suatu organisasi, merupakan salah satu motif yang mendorong manusia untuk selalu menyelidiki seluk-beluk yang terkait dengan kepemimpinan. 
Kualitas dari pemimpin seringkali dianggap sebagai faktor terpenting dalam keberhasilan atau kegagalan organisasi. Menon (2002) keberhasilan atau kegagalan suatu organisasi baik yang berorientasi bisnis maupun publik, biasanya dipersepsikan sebagai keberhasilan atau kegagalan pemimpin. Begitu pentingnya peran pemimpin sehingga isu mengenai pemimpin menjadi fokus yang menarik perhatian para peneliti bidang perilaku keorganisasian. Pemimpin memegang peran kunci dalam memformulasikan dan mengimplementasikan strategi organisasi. Hal ini membawa konsekuensi bahwa setiap pimpinan berkewajiban memberikan perhatian yang sungguh-sungguh untuk membina, menggerakkan, mengarahkan semua potensi karyawan dilingkungannya agar terwujud volume dan beban kerja yang terarah pada tujuan.

Pimpinan perlu melakukan pembinaan yang sungguh-sungguh terhadap karyawan agar dapat menimbulkan kepuasan dan komitmen organisasi sehinga pada akhirnya dapat meningkatkan kinerja yang tinggi (M. Thoha, 2001). Setiap pimpinan di lingkungan organisasi kerja, selalu memerlukan sejumlah pegawai sebagai pembantunya dalam melaksanakan tugastugas yang menjadi volume dan beban kerja unit masing-masing. Hal ini membawa konsekuensi bahwa setiap pimpinan berkewajiban memberikan perhatian yang sungguh-sungguh untuk membina, menggerakkan dan mengarahkan semua potensi pegawai di lingkungannya agar terwujud volume dan beban kerja yang terarah pada tujuan (Marzuki, 2002).

Pimpinan perlu melakukan pembinaan yang sungguh-sungguh terhadap pegawai di lingkungannya agar dapat meningkatkan kepuasan kerja, komitmen organisasi dan kinerja yang tinggi. Gaya kepemimpinan adalah suatu cara yang digunakan oleh seorang pemimpin dalam mempengaruhi perilaku orang lain (Marzuki, 2002). Gaya kepemimpinan merupakan norma perilaku yang dipergunakan oleh seseorang pada saat orang tersebut mencoba mempengaruhi perilaku orang lain. Masing-masing gaya tersebut memiliki keunggulan dan kelemahan. Seorang pemimpin akan menggunakan gaya kepemimpinan sesuai kemampuan dan kepribadiannya

Kinerja pegawai merupakan salah satu faktor utama yang dapat mempengaruhi kemajuan perusahaan. Semakin tinggi atau semakin baik kinerja pegawai maka tujuan perusahaan akan semakin mudah dicapai, begitu pula sebaliknya yang terjadi apabila kinerja pegawai rendah atau tidak baik maka tujuan itu akan sulit dicapai dan juga hasil yang diterima tidak akan sesuai keinginan perusahaan. Kinerja merupakan suatu hal yang tidak dapat dipisahkan dengan perusahaan. Dukungan dari perusahaan berupa pengarahan dari seorang pemimpin, motivasi yang diberikan sebagai penyemangat pegawai, tata tertib yang diterapkan, suasana kerja yang nyaman dan dukungan sumber daya seperti, memberikan peralatan yang memadai sebagai sarana untuk memudahkan pencapaian tujuan yang ingin dicapai sangat diperlukan untuk kinerja pegawai.

Peningkatan kinerja karyawan akan membawa kemajuan bagi perusahaan untuk dapat bertahan dalam suatu persaingan lingkungan bisnis yang tidak stabil. Oleh karena itu upaya-upaya untuk meningkatkan kinerja karyawan merupakan tantangan manajemen yang paling serius karena keberhasilan untuk mencapai tujuan dan kelangsungan hidup perusahaan tergantung pada kualitas kinerja sumber daya manusia yang ada didalamnya.Salah satu tantangan yang dihadapi dalam meningkat kinerja pegawai adalah adanya perbedaan sikap dan perilaku individu dalam bekerja.

Perbedaan sikap dan perilaku tersebut tercermin dalam berbagai hal. Seorang pegawai dapat memiliki kemampuan, sikap 
yang positif dan hubungan antara sesama pegawai akan memberikan pegaruh yang baik terhadap peningkatan pekerjaan.

Perbedaan ini merupakan suatu alasan mengapa para pegawai dalam organisasi menunjukkan tingkat kinerja yang berbedabeda antara pegawai yang satu dengan yang lainnya, misalnya pada pelaksanaan pekerjaan yang belum berdasarkan pada misi organisasi, sehingga banyak program yang dibuat belum sepenuhnya dapat dilaksanakan dan dicapai dengan baik. Diketahui suatu organisasi yang digerakkan oleh misi akan lebih efisien, efektif, fleksibel dan mempunyai kinerja yang lebih tinggi ketimbang yang digerakkan oleh formalisasi atau peraturan-peraturan yang ada.

Menciptakan sebuah kinerja sangat dibutuhkan kekuatan atau pendorong yang akan mewujudkan suatu perilaku tertentu untuk mencapai tujuan dalam kepuasan dirinya. Dengan motivasi yang tinggi akan tercipta sebuah kondisi kinerja yang tinggi pula sehingga pegawai dapat bekerja lebih efektif. Selain dari itu dalam suatu instansi juga diperlukan kedisiplinan pegawai dalam bekerja, tanpa itu maka kinerja tidak mungkin tercapai dengan baik. Hal lain yang juga akan menciptakan kinerja adalah kepemimpinan dalam organisasi disertai promosi dilakukan berdasarkan prestasi pegawai. Secara keseluruhan dengan kepemimpinan dan adanya promosi yang baik seorang pegawai akan bekerja dengan penuh motivasi dan mendorong untuk berpartisipasi aktif.

Berkaitan dengan hal tersebut diatas, dalam rangka meningkatkan kinerja harus didukung oleh semua komponen yang terdapat dalam organisasi dan yang paling penting adalah menumbuhkan kemauan dan keinginan dari setiap pegawai agar mau melakukan perubahan yang menyangkut sikap dan perilaku untuk diimplementasikan secara konsekuen sehingga dalam realitanya dapat dilihat sebagai suatu kinerja pegawai.

Pentingnya peranan aparatur negara, maka perlu mempunyai cara kerja yang formal dan profesional melalui uji kompetensi yang memadai. Guna mencapai "competitive advantage" yang berkelanjutan, maka fokus strategi sumber daya manusia harus segera disesuaikan. Prestasi suatu organisasi tidak terlepas dari prestasi setiap individu yang terlibat di dalamnya yang berdampak langsung dengan kepuasan kerja. Pengembangan penguasaan ilmu pengetahuan atau kemampuan uji kompetensi, supaya kualitas pegawai dapat terus ditingkatkan.

Berdasarkan latar belakang masalah tersebut di atas, maka peneliti tertarik untuk meneliti dengan judul "ANALISIS PENGARUH GAYA KEPEMIMPINAN TERHADAP KINERJA PEGAWAI PT KERETA API INDONESIA (PERSERO) DI TANJUNG KARANG ".

\section{KAJIAN TEORI}

\section{Pengertian Kepemimpinan}

Kepemimpinan mempunyai peranan yang sangat penting dalam manajemen organisasi. Kepemimpinan dibutuhkan manusia karena adanya keterbatasan keterbatasan tertentu pada diri manusia. Dari sinilah timbul kebutuhan untuk memimpin dan dipimpin. Kepemimpinan didefinisikan ke dalam ciri-ciri individual, kebiasan, cara mempengaruhi orang lain, interaksi, kedudukan dalam oragnisasi dan persepsi mengenai pengaruh yang sah.

Menurut Siagian (2004) merumuskan kepemimpinan sebagai suatu kegiatan untuk mempengaruhi perilaku orang-orang agar bekerja bersama-sama menuju suatu tujuan tertentu yang mereka inginkan bersama. Dengan kata lain, kepemimpinan adalah kemampuan mempengaruhi 
kelompok untuk mencapai tujuan kelompok tersebut.

Kepemimpinan adalah pola menyeluruh dari tindakan seorang pemimpin, baik yang tampak maupun yang tidak tampak oleh bawahannya. Kepemimpinan menggambarkan kombinasi yang konsisten dari falsafah, keterampilan, sifat dan sikap yang mendasari perilaku seseorang. Kepemimpinan yang menunjukkan secara langsung maupun tidak langsung tentang keyakinan seorang pimpinan terhadap kemampuan bawahannya (Veithzal, 2006).

Berdasarkan pendapat yang dirumuskan para ahli diatas dapat diketahui bahwa konsepsi kepemimpinan itu sendiri hampir sebanyak dengan jumlah orang yang ingin mendefinisikannya, sehingga hal itu lebih merupakan konsep berdasarkan pengalaman. Hampir sebagian besar pendefinisian kepemimpinan memiliki titik kesamaan kata kunci yakni "suatu proses mempengaruhi". Akan tetapi kita menemukan bahwa konseptualisasi kepemimpinan dalam banyak hal berbeda. Perbedaan dalam hal "siapa yang mempergunakan pengaruh, tujuan dari upaya mempengaruhi, cara-cara menggunakan pengaruh tersebut.

\section{Pengertian Gaya Kepemimpinan}

Ada suatu pendekatan yang dapat digunakan untuk memahami kesuksesan dari kepemimpinan, yakni dengan memusatkan perhatian pada apa yang dilakukan oleh pemimpin tersebut. Jadi yang dimaksud kan disini adalah gayanya. Gaya kepemimpinan merupakan norma perilaku yang digunakan oleh seseorang pada saat orang tersebut mencoba mempengaruhi perilaku orang lain seperti yang ia inginkan.

Gaya kepemimpinan dalam organisasi sangat diperlukan untuk mengembangkan lingkungan kerja yang kondusif dan membangun iklim motivasi bagi karyawan sehingga diharapkan akan menghasilkan produktivitas yang tinggi. Gaya kepemimpinan adalah suatu cara yang digunakan oleh seorang pemimpin dalam mempengaruhi perilaku orang lain. Dari gaya ini dapat diambil manfaatnya untuk dipergunakan sebagai pemimpin dalam memimpin bawahan atau para pengikutnya. Gaya kepemimpinan merupakan norma perilaku yang dipergunakan oleh seseorang pemimpin pada saat mencoba mempengaruhi perilaku orang lain atau bawahan.

Pemimpin tidak dapat menggunakan gaya kepemimpinan yang sama dalam memimpin bawahannya, namun harus disesuaikan dengan karakter-karakter tingkat kemampuan dalam tugas setiap bawahannya. Pemimpin yang efektif dalam menerapkan gaya tertentu dalam kepemimpinannya terlebih dahulu harus memahami siapa bawahan yang dipimpinnya, mengerti kekuatan dan kelemahan bawahannya, dan mengerti bagaimana caranya memanfaatkan kekuatan bawahan untuk mengimbangi kelemahan yang mereka miliki. Istilah gaya adalah cara yang dipergunakan pimpinan dalam mempengaruhi para pengikutnya (Thoha, 2001).

Dalam teori jalur tujuan (Path Goal Theory) Kreitner dan Kinicki, (2005) menyatakan bahwa pemimpin mendorong kinerja yang lebih tinggi dengan cara memberikan kegiatan-kegiatan yang mempengaruhi bawahannya agar percaya bahwa hasil yang berharga bisa dicapai dengan usaha yang serius. Kepemimpinan yang berlaku secara universal menghasilkan tingkat kinerja dan kepuasan bawahan yang tinggi. Dalam situasi yang berbeda mensyaratkan gaya kepemimpinan yaitu karakteristik personal dan kekuatan lingkungan.

Teori ini juga menggambarkan bagaimana persepsi harapan dipengaruhi 
oleh hubungan kontijensi diantara empat gaya kepemimpinan dan berbagai sikap dan perilaku karyawan. Perilaku pemimpin memberikan motivasi sampai tingkat (1) mengurangi halangan jalan yang mengganggu pencapaian tujuan, (2) memberikan panduan dan dukungan yang dibutuhkan oleh para karyawan, dan (3) mengaitkan penghargaan yang berarti terhadap pencapaian tujuan.

\section{Pengertian Kinerja}

Keberhasilan suatu organisasi dipengaruhi oleh kinerja (job performance) sumber daya manusia, untuk itu setiap perusahaan akan berusaha untuk meningkatkan kinerja pegawai dalam mencapai tujuan organisasi yang telah ditetapkan. Budaya organisasi yang tumbuh dan terpelihara dengan baik akan mampu memacu organisasi ke arah perkembangan yang lebih baik.

Disisi lain, kemampuan pemimpin dalam menggerakkan dan memberdayakankan pegawainya akan mempengaruhi kinerja. Istilah kinerja dari kata job performance atau actual performance (prestasi kerja atau prestasi sesungguhnya yang dicapai oleh seseorang). Prestasi kerja pada umumnya dipengaruhi oleh kecakapan, keterampilan, pengalaman dan kesungguhan kerja dari tenaga kerja yang bersangkutan.

Secara etimologi, kinerja berasal dari kata prestasi kerja (performance). Sebagaimana dikemukan oleh Mangkunegara (2007) bahwa isitilah kinerja dari kata kata job performance atau actual performance (prestasi kerja atau prestasi sesungguhnya yang dicapai oleh seseorang) yaitu hasil kerja secara kualitas dan kuantitas yang dicapai oleh seorang pegawai dalam melaksanakan tugasnya sesuai dengan tanggung jawab yang diberikan padanya.
Lebih lanjut Mangkunegara (2007) menyatakan bahwa pada umumnya kinerja dibedakan menjadi dua, yaitu kinerja individu dan kinerja organisasi. Nawawi (2004) menyatakan bahwa, "Kinerja adalah hasil pelaksanaan suatu pekerjaan, baik bersifat fisik/ material maupun non fisik/ non material. Menurut Simanjutak (2005), "Kinerja adalah tingkatan pencapaian hasil atas pelaksanaan tugas tertentu. Simanjuntak juga mengartikan kinerja individu sebagai tingkat pencapaian atau hasil kerja seseorang dari sasaran yang harus dicapai atau tugas yang harus dilaksanakan dalam kurun waktu tertentu".

Foster dan Seeker (2001) menyatakan bahwa, "Kinerja adalah hasil yang dicapai seseorang menurut ukuran yang berlaku untuk pekerjaan yang bersangkutan". Kinerja individu adalah hasil kerja pegawai baik dari segi kualitas maupun kuantitas berdasarkan standar kerja yang telah ditentukan, sedangkan kinerja organisasi adalah gabungan dari kinerja individu dan kinerja kelompok.

\section{Faktor-Faktor yang Mempengaruhi Kinerja}

Menurut Simanjutak (2005) kinerja dipengaruhi oleh :

1. Kualitas dan kemampuan pegawai. Yaitu hal-hal yang berhubungan dengan pendidikan/ pelatihan, etos kerja, motivasi kerja, sikap mental, dan kondisi fisik pegawai.

2. Sarana pendukung, yaitu hal yang berhubungan dengan lingkungan kerja (keselamatan kerja, kesehatan kerja, sarana produksi, teknologi) dan halhal yang berhubungan dengan kesejahteraan pegawai (upah/ gaji, jaminan sosial, keamanan kerja).

3. Supra sarana, yaitu hal-hal yang berhubungan dengan kebijaksanaan 
pemerintah dan hubungan industrial manajemen.

Menurut Sedarmayanti (2007), faktorfaktor yang mempengaruhi kinerja antara lain :1) Sikap dan mental (motivasi kerja, disiplin kerja, dan etika kerja), 2) Pendidikan, 3) Keterampilan, 4) Manajemen kepemimpinan, 5) Tingkat penghasilan, 6) Gaji dan kesehatan, 7) Jaminan sosial, 8) Iklim kerja, 9) Sarana dan prasarana, 10) Teknologi, dan 11) Kesempatan berprestasi.

\section{METODE PENELITIAN}

\section{Objek Penelitian}

Adapun objek penelitian ini adalah PT Kereta Api Indonesia (Persero) di Tanjung Karang Jalan Teuku Umar No 23 penelitian ini dilakukan dari bulan Juni-Juli 2016.

\section{Metode dan Teknik Pengumpulan Data}

Metode yang digunakan dalam penelitian ini adalah metode deskriftif kuantitatif yaitu metode penelitian yang berupa fakta statistik dengan menggunakan angka.

Dalam penelitian ini jenis data yang diperlakukan adalah :

a. Data Primer

Data primer merupakan data dasar yang akan diperoleh langsung tanpa perantara orang atau lembaga lain sebagai pihak ketiga. Data primer ini diperoleh dengan wawancara melalui responden dengan menggunakan daftar pertanyaan.

b. Data Sekunder

Data skunder merupakan data yang diperoleh melalui orang lain yang berhubungan dengan permasalahan yang dipecahkan. Data sekunder ini diperoleh melalui cara studi dokumenter yaitu mengumpulkan dan mempelajari brosurbrosur serta dokumen organisasi.

\section{Sampel dan Populasi}

Berdasarkan pendapat Suharsimi Arikunto (2010) menyatakan bahwa apabila subjeknya kuarng dari 100 lebih baik diambil semua, tetapi apabila subjek lebih dari 100 maka dapat diambil 10\%$15 \%$ atau $15 \%-25 \%$, sehubungan populasi dalam penelitian ini berjumlah 188 maka sampel dalam penelitian ini ditentukan $19 \%$ dari jumlah populasi. Jadi sampel dalam penelitian ini adalah 188x19 \%=35,75 dibulatkan menjadi 36 orang pegawai.

\section{Metode Analisis Data}

Metode analisis data yang digunakan dalam penelitian ini adalah metode analisis kuantitatif dengan rumus Regresi Linier Sederhana :

$$
Y=a+b X+e
$$

Keterangan:

$$
\begin{aligned}
& \mathrm{Y}=\text { Kinerja Pegawai } \\
& \mathrm{a}=\text { Konstanta } \\
& \mathrm{b}=\text { Koefisien regresi } \mathrm{X} \\
& \mathrm{X}=\text { Gaya Kepemimpinan } \\
& \mathrm{e}=\text { Faktor kesalahan }
\end{aligned}
$$

Untuk mengetahui besarnya pengaruh, penghitungan koefisien korelasi tersebut kemudian dilanjutkan dengan Rumus Koefisien Determinasi atau Koefisien Penentu (KP):

$$
K P=(r)^{2} \times 100 \%
$$

Untuk menguji secara hipotesis secara parsial digunakan Uji t dengan rumus :

$$
t_{\text {hitung }}=\frac{r \sqrt{N-2}}{\sqrt{1-r^{2}}}
$$


Keterangan:

$$
\begin{array}{ll}
\mathrm{t}_{\text {hitung }} & =\text { Nilai } \mathrm{t} \\
\mathrm{r} & =\text { Koefisien Korelasi } \\
\mathrm{N} & =\text { Jumlah responden }
\end{array}
$$

Kriteria untuk Uji $t$ adalah sebagai berikut :

a. Apabila nilai $t_{\text {hitung }}<\mathrm{t}_{\text {tabel }}$ atau $\rho<0,05$, maka Ho diterima dan Ha yang berarti variabel independen tidak berpengaruh secara signifikan terhadap variabel dependen.

b. Apabila nilai $t_{\text {hitung }}>t_{\text {tabel }}$ atau $\rho>0,05$ maka Ho ditolak dan Ha diterima yang berarti variabel independen berpengaruh secara signifikan terhadap variabel dependen.

\section{HASIL DAN PEMBAHASAN}

Gaya kepemimpinan merupakan bentuk perilaku yang dapat dibuat mengintegrasikan tujuan dengan tujuan individu, maka gaya kepemimpinan merupakan norma perilaku seseorang yang dipergunakan untuk mempengaruhi orang lain sesuai dengan keinginannya. Pencapaian kinerja bagi pegawai PT Kereta Api Indonesia (Persero) Tanjung Karang belum dapat dikatakan maksimal, karena masih banyak kelemahan dan kekurangan yang harus diperbaiki oleh pegawai PT. Kereta Api Indonesia (Persero) Tanjung Karang hasil penelitian menunjukkan bahwa pencapaian kinerja yang berkaitan dengan pelaksanaan tugas dan tanggung jawab sebagian besar pegawai belum memiliki tanggungjawab yang sama sebagai pelayanan publik dibawah kementrian perhubungan.

Selain itu tugas yang diemban oleh pegawai PT Kereta Api Indonesia (Persero) Tanjung Karang dalam pencapaian kinerja yang dilihat dari aktivitas dalam melaksanakan tugas sehari-hari juga belum dapat diimplementasikan secara optimal tetapi sudah ada upaya dari pimpinan PT Kereta Api Indonesia (Persero) Tanjung Karang untuk melakukan evaluasi dan audit kinerja dengan tujuan kinerja pegawai PT Kereta Api Indonesia (Persero) Tanjung Karang akan semakin meningkat.

\section{Uji Validitas}

Uji vaiditas dilakukan dengan menggunakan rumus korelasi produk moment yang dikembangkan oleh Ghozali, (2005), adapun kriteria pengujian yaitu: Apabila $r_{\text {hitung }}>r_{\text {tabel }}$ maka valid Apabila $\mathrm{r}_{\text {hitung }}<\mathrm{r}_{\text {tabel }}$ maka tidak valid

Uji validitas ini setiap item pertanyaan diuji validitasnya, untuk mengetahui validitasnya setiap item pertanyaan dalam instrument penelitian dapat dilihat melalui kolom corrected item-total correlation. Setelah dilakukan uji validitas Gaya Kepemimpinan (X) diketahui bahwa 20 butir item pertanyaan di atas maka dapat dinyatakan 20 butir item valid karena mimiliki nilai corrected item-total correlation > 0.339. Sedangkan variabel kinerja pegawai(Y) item pernyataan sebanyak 20 butir dari ke-20 penyataan tersebut dinyatakan instramen valid semua karena mimiliki nilai corrected item-total correlation $>0.339$.

\section{Uji Reliabilitas Data}

Pengujian reabilitas kuisioner dalam penelitian ini menggunakan one shop atau pengukuran sekali saja dan untuk pengujian realibilitasnya di gunakan uji statistik Cronbach Alpha, suatu konstruk atau variabel dikatakan reliabel jika memberikan nilai Cronbach Alpha > 0.60. Berdasarkan uji reliabilitas menunjukkan bahwa Cronbach Alpha untuk variabel gaya kepemimpinan memiliki nilai $0.861>0.60$ dan untuk variabel kinerja memiliki nilai $0.881>0.60$, berdasarkan hasil tersebut 
maka semua instrument variabel dalam penelitian ini adalah reliabel (konsisten) ini dikarenenakan nilai Cronbach Alpha > 0.60 .

\section{Analisis Kuantitatif}

Berdasarkan descriptive statistics menunjukkan rata-rata skor gaya kepemimpinan dari jumlah sampel 36 sebesar 82,58dengan standar deviasi sebasar 5,484 dan rata-rata skor kinerja pegawai sebasar 86,81 dengan standar deviasi sebasar 5,476, berdasarkan nilai rata-rata skor di atas maka diketahui bahwa gaya kepemimpinan dan Kinerja Pegawai PT. Kereta Api Indonesia (Persero) Tanjung Karang memiliki nilai interval yang tidak jauh sehingga dapat diasumsikan bahwa indikator yang penulis tawarkan kepada responden sesuai dengan fakta empiris pada PT Kereta Api Indonesia (Persero) Tanjung Karang.

Berdasarkan perhitungan maka dapat diketahui bahwa terdapat hubungan antara gaya kepemimpinan dengan kinerja pegawai PT. Kereta Api Indonesia (Persero) Tanjung Karang dengan $\mathrm{r}_{\text {hitung }}>$ $r_{\text {tabel }}$ atau $1.000>0.261$ (hasil intervolusi pada $\mathrm{a}=0.05$ dan $\mathrm{n}=36$ ) dengan demikian HO ditolak dan Ha diterima atau dengan probalitas (sig) $0.000>0.05$ maka ada hubungan positif signifikan antara gaya kepemimpinan pegawai dengan Kinerja pegawai PT Kereta Api Indonesia (Persero) Tanjung Karang.

Hasil di atas dikoefisien determinasi $(R$ Square) sebesar 0.112 atau secara statistik 33,4\% Kinerja PT Kereta Api Indonesia (Persero) Tanjung Karang dipengaruhi oleh gaya kepemimpinan. Sedangkan sisanya $(100 \%-33,4 \%)=66,6 \%$ kinerja pegawai PT Kereta Api Indonesia (Persero) Tanjung Karang dipengaruhi oleh faktor-faktor lain selain variabel bebas yang sedang penulis teliti.
Berdasarkan perhitungan diperoleh koefisien regresi sebesar 14,080 dan konstanta sebesar 53.549, maka dapat digambarkan bentuk hubungan variabel gaya kepemimpinan dengan kinerja pegawai dalam bentuk persamaan regersi $\mathrm{Y}$ $=53.549+334 \mathrm{X}$ ini berarti bahwa jika gaya kepemimpian meningkat sebesar 1 poin maka kinerja pegawai akan meningkat sebesar 2,066 poin pada konstanta 53,549. Sehingga dengan kata lain bahwa semakin baik gaya kepemimpinan seorang maka kinerja pegawai akan semakin tinggi sehingga berdampak kepada kemajuan dan program kerja yang akan dikerjakan.

Berdasarkan tabel di atas thitung untuk Gaya Kepemimpinan pegawai sebesar 2,066 sedangkan tabel sebesar dengan $\mathrm{dk}$ $(36-2=34)$ adalah 1.689 , jadi thitung $2,066>$ $\mathrm{t}_{\text {tabel }} 0.05(\mathrm{dk} 34)=1.689$, sehingga dengan demikian $\mathrm{Ho} 2$ ditolak $\mathrm{Ha} 2$ diterima dapat disimpulkan bahwa memang terdapat pengaruh yang signifikan antara gaya kepemimpinan terhadap kinerja pegawai PT. Kereta Api Indonesia (Persero) Tanjung Karang.

\section{KESIMPULAN DAN SARAN}

\section{Kesimpulan}

Berdasarkan hasil penelitian dapat disimpulkan bahwa diperoleh $t_{\text {hitung }}$ untuk Gaya Kepemimpinan sebesar 4,629 sedangkan $t_{\text {tabel }}$ sebesar dengan $\mathrm{dk}$ (36-2 34) adalah 1.689, jadi $t_{\text {hitung }} 4,629>t_{\text {tabel }}$ $0.05(36-2=34)=1-689$, sehingga dapat diketahui bahwa gaya kepemimpinan berpengaruh positip signifikan terhadap Kinerja pegawi pada PT. Kereta Api Indonesia (Persero) Tanjung Karang, selain itu semakin baik gaya kepemimpinan yang dilakukan maka kinerja pegawai dalam berkerja, sehingga berdampak kepada kemajuan dan kualitas sumber daya manusia. Sedangkan dari hasil nilai Koefesien Determinasi $(R \quad$ Square $)$ 
diperoleh nilai sebesar 0,334 atau secara statistik 33,4\% Kinerja Pegawai pada PT. Kereta Api Indonesia (Persero) Tanjung Karang dipengaruhi oleh Gaya Kepemimpinan. Sedangkan sisanya $(100 \%-33,4 \%)=66,6 \%$ Kinerja Pegawai PT Kereta Api Indonesia (Persero) Tanjung Karang dipengaruhi oleh faktor-faktor lain selain variabel yang sedang penulis teliti.

\section{Saran}

Berdasarkan hasil kesimpulan di atas maka penulis memberikan rekomendasi kepada pihak terkait dengan tujuan pegawai PT Kereta Api Indonesia (Persero) Tanjung Karang dapat menjadikan gaya kepemimpinan sebagai alat untuk menjalin hubungan yang sinergis didalam meningkatkan kinerja pegawai PT Kereta Api Indonesia (Persero) Tanjung Karang:

1. Pimpinan pegawai PT Kereta Api Indonesia (Persero) Tanjung Karang hendaknya didalam memberikan perintah kerja kepada bawahan sesuai dengan struktur organisasi yang ada di PT Kereta Api Indonesia (Persero) Tanjung karang.

2. Pegawai PT Kereta Api Indonesia (Persero) Tanjung Karang hendaknya berkerja sesuai dengan kemampuan atau kompetensi yang dimiliki pegawai supaya tidak terjadi saling berbenturan dengan pekerjaan pokok yang sesuai dengan kompetensi yang dimilinya

\section{DAFTAR PUSTAKA}

Arikunto, Suharsimi. 2011. Statistik dan Aplikasi. Jakarta: Penerbit Erlangga.

Basu, Swastha dan Ibnu Sukotjo. 2002. Manajemen Pemasaran Modern. Yogyakarta: Liberty.
Basu, Swastha dan Irawan. 2008. Manajemen Pemasaran Modern. Yogyakarta: Liberty.

Harnanto. 2008. Akuntansi Keuangan Intermediete. Yogyakarta: Liberty.

Hasibuan, Malayu SP. 2005. Manajemen Sumber Daya Manusia. Edisi Revisi. Jakarta: PT Bumi Aksara.

Iswara, Medy. 2016. Pengaruh Biaya Promosi Terhadap Penjualan Produk Indosat Di Bandar Lampung. Skripsi. Fakultas Ekonomi Program Studi Manajemen Universitas Bandar Lampung.

Kotler, Philip dan Garry Amstrong. 1997. Prinsip-prinsip Pemasaran Edisi Ketiga. Jakarta: Erlangga.

Kotler, Philip dan Amstrong. 2004. PrinsipPrinsip Pemasaran. Alih Bahasa Oleh Wisnu Chandra Kristiaji Jilid 2 Edisi Ke 8. Jakarta: Erlangga.

Kotler, Philip. 2005. Manajemen Pemasaran Jilid 1. Klaten: PT. Intan Sejati.

Kotler, Philip dan Susanto. 2008. Manajemen Pemasaran Di Indonesia. Jakarta: Salemba Empat.

Machfoedz. 2000. Akuntansi Manajemen. Yogyakarta: BPFE.

R Don, Hansen dan Maryanne M. Mowen. 2000. Akuntansi Manajemen, Edisi Ke Dua,terjemahan. Jakarta: Erlangga.

Simamora, Henry. 2002. Manajemen Pemasaran Internasional. Surabaya: Pustaka Utama.

Stanton. 2002. Prinsip-Prinsip Pemasaran. Jakarta: Erlangga. 
Icha Annisa Putri : Analisis Pengaruh Gaya Kepemimpinan Terhadap Kinerja Pegawai Pada PT. Kereta Api Indonesia (Persero) Tanjung Karang

Sugiyono. 2011. Statistik Untuk Penelitian.

Cetakan 4. Bandung: Alfabeta.

Tjiptono. 1999. Strategi Pemasaran. Yogyakarta: Liberty.

Uyanto, S, Stanislaus. 2006. Pedoman Analisis Data dengan SPSS. Edisi Pertama. Cetakan Pertama. Yogyakarta: Graha Ilmu. 